\title{
PENGARUH PENGGUNAAN BRAINLY TERHADAP HASIL BELAJAR SISWA
}

\author{
Rafif Aditya Nugroho \\ Fakultas Ilmu Pendidikan, Universitas Negeri Yogyakarta \\ e-mail: rafifaditya.2020@student.uny.ac.id
}

\begin{abstract}
Abstrak
Kemajuan teknologi yang sangat cepat dari waktu ke waktu kadang juga bisa menimbulkan dampak negatif. Para siswa dikhawatirkan semakin bergantung dengan kecanggihan yang diberikan teknologi saat ini. Penelitian ini bertujuan untuk mengetahui pengaruh penggunaan Brainly terhadap hasil belajar siswa saat pembelajaran di sekolah. Metode yang digunakan adalah metode kuantitatif dengan teknik pengumpulan data berupa kuesioner. Hasil dari penlitian ini adalah Brainly menjadi sebuah platform yang sering digunakan para siswa dalam membantu menyelesaikan pekerjaan sekolah. Aplikasi Brainly terbukti dapat meningkatkan hasil belajar siswa, namun disamping itu juga berdampak negatif terhadap cara belajar siswa di kelas.
\end{abstract}

Kata Kunci: kemajuan teknologi, siswa, Brainly, hasil belajar

\section{THE EFFECT OF USING BRAINLY ON STUDENT LEARNING OUTCOMES}

\begin{abstract}
Technological advances are very fast from time to time sometimes can also have a negative impact. It is feared that students are increasingly dependent on the sophistication of today's technology. This study aims to determine the effect of using Brainly on student learning outcomes when learning at school. The method used is a quantitative method with data collection techniques in the form of distributing questionnaires. The result of this research is that Brainly has become a platform that is often used by students to help complete their schoolwork. The Brainly application is proven to improve student learning outcomes, but besides that it also has a negative impact on the way students learn in the classroom.
\end{abstract}

Keywords: technological progress, students, Brainly, learning outcomes

\section{PENDAHULUAN}

Perkembangan teknologi saat ini tumbuh begitu pesat, bahkan sudah masuk dalam dunia pendidikan. Banyak media pembelajaran saat ini sudah sarat akan teknologi, seperti situs web pembelajaran, aplikasi-aplikasi pembelajaran, dan perangkat teknologi lainnya. Menurut Rosentberg (2001), Perkembangan penggunaan teknologi di ranah pendidikan menyebabkan beberapa perubahan dalam proses pembelajaran, yaitu: pembelajaran yang awalnya hanya dilakukan di ruang kelas menjadi bisa dilakukan kapan saja dan dimana saja, pembelajaran yang berbasis kertas berubah menjadi online, fasilitas fisik di kelas seperti buku tulis, papan tulis, dan alat tulis mulai tergantikan dengan fasilitas jaringan kerja yang disediakan di internet seperti sosial media, blog, e-book, dan e-mail. Siswa juga bisa memperoleh materi pembelajaran secara langsung melalui internet tanpa harus menunggu waktu materi pembelajaran diberikan oleh guru. Interaksi antara guru dan murid dapat dilakukan dengan menggunakan media-media komunikasi seperti komputer, internet, telepon, e-mail, dan sebagainya. Hal ini membuat proses pembelajaran dapat dilakukan tanpa harus melakukan pembelajaran tatap muka di sekolah (Rosentberg, 2001).

Perkembangan teknologi saat ini memunculkan berbagai macam aplikasi yang berguna untuk membantu pembelajaran siswa, salah satunya adalah aplikasi Brainly. Brainly adalah sebuah aplikasi belajar yang memungkinkan penggunanya untuk saling tanya jawab dan bediskusi mengenai pertanyaan terkait dengan pelajaran di sekolah. Aplikasi ini bisa didownload gratis di Playstore maupun Appstore. Brainly menyediakan 25 kategori pelajaran mulai dari tingkatan SD hingga SMA. Siswa, orang tua, dan guru bisa menggunakan aplikasi ini untuk bertanya dan 
menjawab pertanyaan. Kita bisa langsung bertanya apapun terkait pembelajaran di sekolah menggunakan aplikasi Brainly. Aplikasi ini sangat berguna bagi siswa karena kita bisa langsung mendapatkan jawaban tanpa harus mencari dari berbagai sumber. Hal ini bisa dimanfaatkan oleh siswa dalam mengerjakan tugas tanpa harus membaca buku lagi. Siswa menjadi malas belajar dan bergantung pada aplikasi-aplikasi semacam Brainly ini. Brainly bahkan sudah didownload lebih dari 50 juta pengguna di Playstore.

Kemajuan teknologi yang sangat cepat dari waktu ke waktu kadang juga bisa menimbulkan dampak negatif. Para siswa dikhawatirkan semakin bergantung dengan kecanggihan yang diberikan teknologi saat ini. Ada beberapa penelitian yang menyebutkan bahwa kecanggihan teknologi membuat minat baca para siswa menurun. Hal ini berdasarkan hasil survey yang dilakukan oleh UNESCO pada tahun 2016 yang menyebutkan bahwa minat baca masyarakat Indonesia menduduki peringkat 60 dari 61 negara. (Evita, 2017). Hasil ini mengindikasikan bahwa minat baca masyarakat Indonesia sangat rendah. Minat baca siswa yang rendah akan berpengaruh pada kualitas pendidikan. Siswa yang tidak memiliki keinginan untuk membaca akan berakibat pada rendahnya tingkat pengetahuan dan kualitas diri mereka. Siswa yang memiliki minat baca yang rendah tidak memanfaatkan waktu luang mereka untuk membaca tetapi melakukan kegiatan lain seperti bermain dan sebagainya. (Soetminah dalam Meity \& Ramadani, 2015: 33). Rendahnya minat baca ini membuat para siswa menjadi malas untuk mencari sumber informasi dari buku. Para siswa lebih memilih cara instan dengan mencarinya lewat internet, salah satunya adalah aplikasi Brainly ini.

Oleh karena itu, penelitian ini akan membahas tentang apa itu Brainly, berapa banyak siswa yang menggunakan aplikasi Brainly, dan dampak aplikasi Brainly terhadap hasil belajar siswa. Peneliti ingin mengetahui pengaruh Brainly terhadap hasil belajar siswa di sekolah. Peneliti ingin membuktikan apakah para siswa memiliki ketergantungan pada kemudahan teknologi yang ada saat ini. Diharapkan melalui penelitian ini dapat dijadikan pertimbangan oleh pendidik dan orang tua siswa untuk selalu mengawasi anakanak didiknya dalam memanfaatkan teknologi dalam pembelajaran di sekolah ataupun di rumah.

\section{METODE}

Metode penelitian yang digunakan adalah metode kuantitatif. Metode penelitian kuantitatif adalah suatu metode yang digunakan untuk menganalisis tentang hal yang ingin diteliti menggunakan data berupa angka-angka. (Kasiram (2008: 149). Dalam penelitian ini, instrumen yang digunakan untuk mencari data adalah kuesioner. Kuesioner yang digunakan berupa kuesioner online yang dibuat melalui google formulir. Peneliti menyebarkan kuesioner kepada 30 responden, dimana setiap responden harus menjawab 17 item pertanyaan mengenai pengaruh penggunaan aplikasi Brainly terhadap hasil belajar siswa. Jawaban yang diberikan responden akan digunakan untuk membantu melakukan pembahasan hasil. Melalui metode ini, peneliti ingin mengetahui pengaruh penggunaan Brainly terhadap hasil belajar siswa berdasarkan jawaban yang diberikan oleh responden.

Populasi atau sampel dalam penelitian ini adalah siswa/siswi dari SD-SMA yang ada di Yogyakarta. Peneliti membagikan kuesioner ke grub Whatsapp pada masingmasing jenjang pendidikan. Peneliti meminta salah satu siswa di masing-masing jenjang pendidikan yaitu SD, SMP, dan SMA untuk membagikan link kuesioner ke grub mereka. Dalam penelitian ini, peneliti menggunakan teknik random sampling. Siswa yang dijadikan sebagai sampel dipilih secara acak melalui link yang dibagikan peneiti. Siswa yang mengisi kuesioner tersebut yang akan dijadikan sebagai sampel penelitian.

\section{HASIL DAN PEMBAHASAN Hasil}

Kuesioner yang dibagikan peneliti bertujuan untuk mengetahui pengaruh Brainly terhadap hasil belajar siswa di sekolah. Peneliti ingin membuktikan apakah para siswa memiliki ketergantungan pada kemudahan teknologi yang ada saat ini. Dari hasil kuesioner yang dibagikan, diperoleh data sebagai berikut : 
Diagram 1.1 Versi Brainly

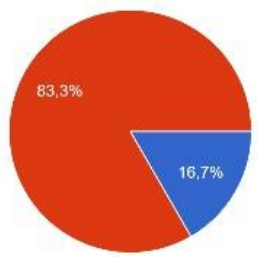

Data yang diperoleh dari kuesioner yang dibagikan oleh peneliti, dari 30 responden yang mengisi kuesioner tercatat semuanya sudah pernah menggunakan Brainly. Rincian data yang diperoleh diketahui sebanyak $83,3 \%$ atau sebanyak 25 responden menggunakan Brainly dalam versi website, kemudian sisanya sebanyak $16,7 \%$ atau sebanyak 5 responden menggunakan Brainly dalam versi aplikasi.

\section{Diagram 1.2 Penggunaan Brainly}

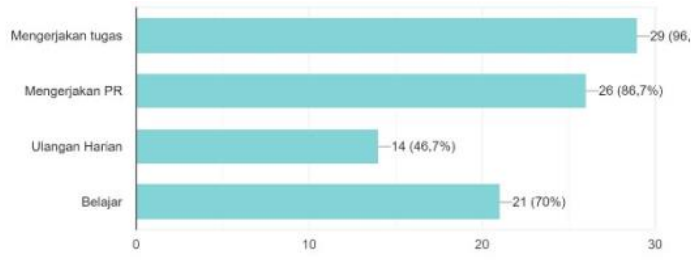

Bedasarkan diagram diatas dapat diketahui keperluan siswa dalam menggunakan Brainly. Dari 30 responden diperoleh data sebagai berikut : Sebanyak 29 orang pernah menggunakan Brainly untuk mengerjakan tugas, sebanyak 26 orang pernah menggunakan Brainly untuk mengerjakan PR, sebanyak 14 orang menggunakan Brainly untuk mengerjakan ulangan harian, sebanyak 21 orang pernah menggunakan Brainly untuk belajar. Dari data tersebut dapat diketahui bahwa Brainly menjadi salah satu sumber belajar yang sering digunakan siswa dalam mengerjakan pekerjaan sekolah.

\section{Diagram 1.3 Penggunaan Brainly untuk tugas}

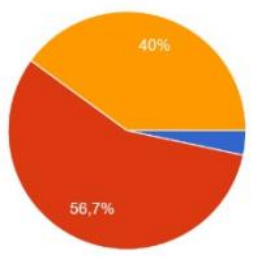

Hasil perhitungan pada diagram penggunaan Brainly untuk kebutuhan mengerjakan tugas diatas menginformasikan bahwa dari 30 responden paling banyak 56,7\% atau sebanyak 17 responden menjawab kadang-kadang. Responden lain sebanyak $40 \%$ atau 12 responden menjawab sering, dan sebanyak 3,3\% atau 1 orang menjawab selalu dalam menggunakan Brainly untuk mengerjakan tugas.

\section{Diagram 1.4 Penggunaan Brainly untuk PR}

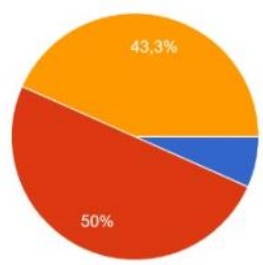

Hasil perhitungan pada diagram penggunaan Brainly untuk kebutuhan mengerjakan PR diatas menginformasikan bahwa dari 30 responden paling banyak 50\% atau sebanyak 15 responden menjawab kadang-kadang. Responden lain sebanyak $43,3 \%$ atau 13 responden menjawab sering, dan sebanyak 6,7\% atau 2 orang menjawab sering dalam menggunakan Brainly untuk mengerjakan PR.

\section{Diagram 1.5 Penggunaan Brainly untuk Ulangan Harian}
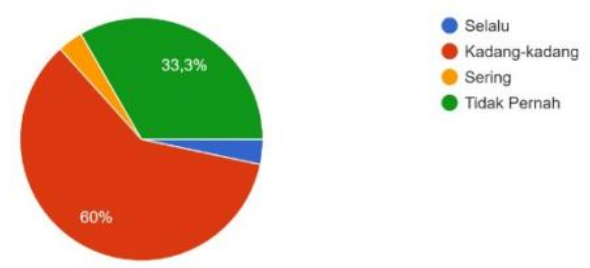

Hasil perhitungan pada diagram penggunaan Brainly untuk kebutuhan mengerjakan Ulangan Harian menginformasikan bahwa dari 30 responden paling banyak $60 \%$ atau sebanyak 18 responden menjawab kadang-kadang. Responden lain sebanyak $33,3 \%$ atau 10 responden menjawab tidak pernah, dan sebanyak masing-masing $3,3 \%$ atau 1 orang menjawab sering dan selalu dalam menggunakan Brainly untuk mengerjakan ulangan harian. 


\section{Diagram 1.5 Penggunaan Brainly untuk Belajar}

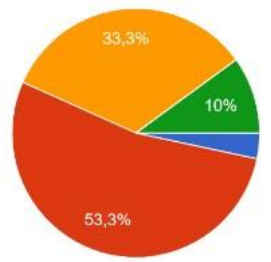

Hasil perhitungan pada diagram penggunaan Brainly untuk kebutuhan belajar diatas menginformasikan bahwa dari 30 responden paling banyak 53,3\% atau sebanyak 16 responden menjawab kadangkadang. Responden lain sebanyak $33,3 \%$ atau 10 responden menjawab sering, dan sebanyak $10 \%$ atau 3 orang menjawab tidak pernah dan sebanyak 3,3\% atau 1 responden menjawab selalu dalam menggunakan Brainly untuk belajar.

\section{Diagram 1.6 Kepuasan Jawaban}

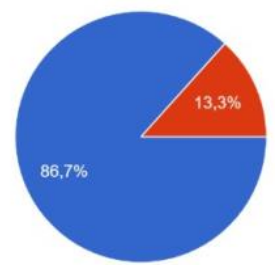

Hasil perhitungan pada diagram kepuasan responden terhadap jawaban yang diberikan oleh Brainly diatas menginformasikan bahwa dari 30 responden paling banyak $86,7 \%$ atau sebanyak 26 responden menjawab puas dengan jawaban yang diberikan Brainly sedangkan sisanya sebanyak $13,3 \%$ atau 4 responden menjawab tidak puas.

\section{Diagram 1.7 Hasil Belajar}

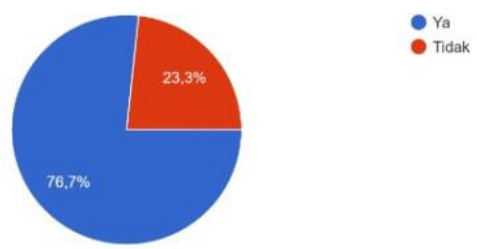

Hasil perhitungan pada diagram kepuasan responden terhadap hasil belajar

menggunakan

Brainly

diatas menginformasikan bahwa dari 30 responden paling banyak $76,7 \%$ atau sebanyak 23 responden mendapat hasil belajar yang memuaskan dengan menggunakan Brainly, sedangkan sisanya sebanyak $23,3 \%$ atau 7 responden menjawab tidak puas.

\section{Tabel 1.8 Penilaian hasil belajar}

\begin{tabular}{|c|c|}
\hline Nilai & Frekuensi \\
\hline 4 & 4 \\
\hline 5 & 1 \\
\hline 6 & 5 \\
\hline 7 & 1 \\
\hline 8 & 17 \\
\hline 9 & 2 \\
\hline Total & $\mathbf{2 1 2}$ \\
\hline Rata-rata & $\mathbf{7 , 0 6}$ \\
\hline
\end{tabular}

Berdasarkan table di atas dapat diketahui bahwa responden paling banyak memberi nilai 8 pada kuesioner tentang pengaruh Brainly terhadap hasil belajar. Responden yang memberi nilai 8 sebanyak 17 orang dari total 30 responden yang mengisi kuesioner. Nilai paling rendah yang diberikan responden pada penilaian ini adalah 4 dengan jumlah 4 responden dan nilai paling tinggi yang diberika adalah 9 sebanyak 2 orang responden. Rata-rata penilaian penggunaan Brainly terhadap hasil belajar siswa yaitu 7,06 dengan nilai yang paling banyak diberikan yaitu 8 . Hal ini membuktikan bahwa adanya Brainly dapat berpengaruh baik pada hasil belajar siswa di kelas.

Tabel 1.10 Penilaian Manfaat Brainly

\begin{tabular}{|c|c|}
\hline \multicolumn{1}{|l|}{ Nilai } & Frekuensi \\
\hline 4 & 1 \\
\hline 5 & 1 \\
\hline 6 & 2 \\
\hline 7 & 6 \\
\hline 8 & 17 \\
\hline 9 & 2 \\
\hline 10 & 1 \\
\hline Total & $\mathbf{2 2 7}$ \\
\hline Rata-rata & $\mathbf{7 , 5 6}$ \\
\hline
\end{tabular}


Berdasarkan table diatas dapat diketahui bahwa responden paling banyak memberi nilai 8 pada kuesioner tentang penilaian manfaat yang diberikan Brainly. Responden yang memberi nilai 8 sebanyak 17 orang dari total 30 responden yang mengisi kuesioner. Nilai paling rendah yang diberikan responden pada penilaian ini adalah 4 dengan jumlah satu responden dan nilai paling tinggi yang diberika adalah 10 sebanyak 1 orang responden. Rata-rata penilaian manfaat penggunaan yaitu 7,56 dengan nilai yang paling banyak diberikan yaitu 8. Hal ini membuktikan bahwa Brainly memberi dampak yang baik untuk penggunanya terutama dalam memberikan jawaban terhadap soal yang ditanyakan oleh penggunanya.

\section{Diagram 1.11 Dampak Negatif Penggunaan Brainly}
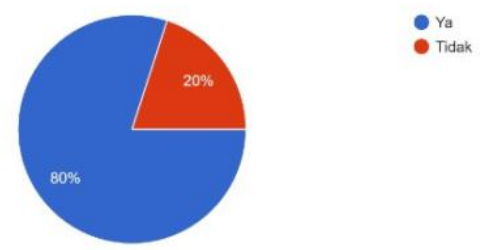

Hasil perhitungan pada diagram diatas menginformasikan bahwa dari 30 responden paling banyak $80 \%$ atau sebanyak 24 responden menyadari bahwa menggunakan Brainly akan berdampak negative pada cara belajar mereka, sedangkan sisanya sebanyak $20 \%$ atau 6 responden menjawab bahwa Brainly tidak menimbulkan dampak negatif pada cara belajar mereka. Hal ini menunjukkan bahwa mereka sadar ketika menggunakan Brainly akan berdampak negatif pada cara belajar mereka kedepannya.

\section{Pembahasan}

Brainly adalah sebuah platform yang diciptakan untuk memudahkan pengguna dalam menyelesaikan pekerjaan sekolah. Dalam platform ini sesama pengguna pengguna Brainly bisa saling bertukar pertanyaan dan jawaban. Dengan kata lain Brainly adalah sebuah platform media sosial berbasis pendidikan yang menghubungkan pengguna satu dengan pengguna lainnya untuk saling bertukar pertanyaan dan jawaban. Brainly menjadi platform yang sering dipilih siswa dalam mencari jawaban tentang pekerjaan sekolah mereka.
Dari survei yang peneliti lakukan dapat diketahui bahwa semua responden yang mengisi kuesioner pernah menggunakan Brainly untuk mengerjakan pekerjaan sekolah. Dari 30 responden yang mengisi kuesioner diketahui bahwa versi Brainly yang paling banyak digunakan adalah versi website dibandingkan dengan versi aplikasi. Responden yang memilih versi website kebanyakan beralasan bahwa versi website lebih cepat dan praktis dalam mencari jawaban sedangkan responden yang memilih aplikasi beralasan bahwa versi tersebut dinilai lebih nyaman dan mudah digunakan.

Dalam kuesioner tentang penggunaan Brainly, Responden paling banyak memilih kadang-kadang dan sering untuk keperluan mengerjakan pekerjaan sekolah seperti, mengerjakan tugas, mengerjakan PR, belajar bahkan sampai ulangan harianpun masih ada beberapa siswa yang menggunakan Brainly. Dalam hal ini dapat diketahui bahwa Brainly menjadi menjadi referensi yang sering dipilih peserta didik untuk mencari jawaban.

Menurut Selwyn (2011), dampak dari kemajuan teknologi digital berperan penting dalam proses pembelajaran terutama pada aspek kognitif siswa. Salah satu contoh kemajuan teknologi adalah adanya internet. Masuknya internet dalam proses pembelajaran memudahkan siswa untuk mencari informasi dari berbagai sumber. Saat ini siswa sudah tidak perlu membeli buku-buku di toko atau mencari di perpustakaan untuk mendapatkan sumber belajar. Siswa cukup mencari informasi yang ingin dipelajari di internet. Dalam hal ini Brainly menjadi alat/media sumber belajar yang digunakan siswa untuk menyelesaikan pekerjaan mereka. Brainly bisa menggantikan peran buku sebagai sumber belajar utama peserta didik dikelas. Mereka lebih memilih Brainly sebagai referensi materi karena lebih cepat mendapatkan jawaban dibandingkan dengan membaca buku yang memerlukan waktu yang lebih lama. Jawaban yang diberikan Brainly juga memuaskan, sebanyak 25 responden merasa puas dengan jawaban yang terdapat pada Brainly. Hal ini menjadi faktor penguat bahwa Brainly dapat menggantikan buku sebagai sumber belajar siswa.

Kemudian pada kuesioner penilaian manfaat penggunaan Brainly, kebanyakan 
responden memberi nilai 8 dengan nilai ratarata 7,56. Peneliti merangkum beberapa pendapat responden mengenai manfaat yang diperoleh ketika menggunakan Brainly. Berdasarkan pendapat yang diungkapkan responden, manfaat penggunaan Brainly dapat diketahui sebagai berikut :

1. Cepat mendapatkan jawaban.

Adanya Brainly dapat memudahkan siswa mendapatkan jawaban dengan cepat, jawaban yang terdapat di Brainy umumnya berupa jawaban singkat dan langsung pada pokok permasalahan yang ditanyakan.

2. Bisa berdiskusi dengan sesama pengguna.

Saat menggunakan Brainly, pengguna dapat berdiskusi dan bertukar pendapat dengan pengguna Brainly yang lain, karena Brainly menyediakan kolom komentar yang langsung bisa digunakan oleh pengguna untuk bisa saling bertukar pendapat mengenai sebuah topik atau permasalahan yang sedang di bahas.

3. Mudah mendapatkan referensi jawaban. Brainly memudahkan pengguna untuk mendapatkan referensi jawaban dari pengguna Brainly yang lain, karena satu pertanyaan yang diajukan bisa ditanggapi / dijawab oleh lebih dari satu orang pengguna Brainly yang lain. Jadi sesama pengguna Brainly bisa saling menambahkan jawaban atau bisa saling mengoreksi jika ada jawaban yang salah.

\section{Meningkatkan hasil belajar}

Brainly juga berpengaruh baik terhadap hasil belajar siswa. Beberapa responden mengaku hasil belajarnya naik ketika menggunakan Brainly. Mereka bisa menjawab soal-soal sulit dengan cepat menggunakan Brainly. Dari 30 responden yang mengisi kuesioner, sebanyak 17 responden memberikan nilai 8 untuk pengaruh Brainly terhadap hasil belajar siswa. Hal ini membuktikan bahwa Brainly memberi manfaat yang signifikan terutama pada hasil belajar siswa

Namun terlepas dari manfaat dan hasil belajar yang diperoleh pengguna Brainly, sebanyak 24 responden dari 30 orang yang mengisi kuesioner menyadari bahwa penggunaan Brainly secara terus menerus akan berdampak negatif pada cara belajar mereka.
Hal ini sejalan dengan penelitian yang dilakukan oleh Novi dan Dwi pada tahun 2020 tentang analisa dampak perkembangan teknologi informasi dan komunikasi dalam bidang pendidikan. Mereka menyebutkan bahwa kemudahan yang diberikan oleh teknologi dapat menumbuhkan sifat ketergantungan. Para pengguna teknologi informasi semakin meninggalkan alat-alat manual dengan alasan efisiensi. Jika hal ini berlangsung lama maka akan mengubah pola perilaku individu dalam segala aktivitasnya. Dalam hal ini Brainly bisa dikatakan sebagai kemudahan teknologi yang ada di dunia pendidikan terutama pada proses pembelajaran. Jika Brainly digunakan oleh siswa secara terus menerus akan menimbulkan dampak negatif dalam hal cara belajar mereka

Peneliti sudah merangkum beberapa alasan yang diberikan responden tentang dampak negatif apabila menggunakan Brainly secara terus menerus. Berdasarkan pendapat yang diungkapkan responden, dampak negatif penggunaan Brainly dapat diketahui sebagai berikut:

1. Menumbuhkan rasa malas.

Responden paling banyak memberi alasan apabila siswa menggunakan Brainly secara terus menerus akan menumbuhkan rasa malas dalam membaca dan memahami materi yang sebenarnya.

2. Menimbulkan ketergantungan

Siswa bisa menjadi ketergantungan menggunakan Brainly karena terus memperoleh jawaban secara instan yang menjadikan siswa menjadi malas mencari referensi belajar dari sumber yang lain karena jawaban sudah tersedia di Brainly.

3. Membiasakan siswa menjadi pasif

Responden lain juga beralasan bahwa Brainly akan membuat siswa menjadi pasif dan selalu ingin memperoleh jawaban yang praktis dan cepat. Beberapa jawaban yang diberikan Brainly biasanya tersaji tanpa disertai alasan yang melatarbelakanginya, hal ini membuat para siswa seakan-akan hanya peduli dengan jawaban tetapi tidak ingin tahu cara/alasan dari jawaban tersebut.

\section{PENUTUP}

Brainly menjadi sebuah platform yang sering digunakan para siswa untuk membantu mereka dalam mengerjakan pekerjaan sekolah seperti mengerjakan tugas, mengerjakan PR, 
belajar, bahkan sampai digunakan untuk mengerjakan ulangan harian. Dari survei yang dilakukan peneliti dapat diketahui bahwa semua responden yang mengisi kuesioner atau sebanyak 30 responden pernah menggunakan Brainly untuk mengerjakan pekerjaan sekolah.

Adapun terkait kepuasan siswa dalam penggunaan Brainly, mayoritas responden sebanyak $86,7 \%$ menjawab puas dengan jawaban yang diberikan Brainly sedangkan sisanya sebanyak 13,3\% menjawab tidak puas. Kemudian untuk hasil belajar, sebanyak $76,7 \%$ responden mendapat hasil belajar yang memuaskan dengan menggunakan Brainly, sedangkan sisanya sebanyak 23,3\% mendapatkan hasil yang kurang memuaskan.

Sementara itu untuk penilaian manfaat Brainly, rata-rata penilaian yang diberikan yaitu 7,56 dengan nilai yang paling banyak diberikan yaitu 8 sebanyak 17 orang. Kemudian untuk nilai paling rendah yang diberikan responden pada penilaian ini adalah 4 sebanyak 1 orang dan nilai paling tinggi yang diberikan adalah 10 sebanyak 1 orang.

Namun terlepas dari manfaat yang diberikan oleh Brainly, banyak responden yang menyadari bahwa penggunaan Brainly akan membawa dampak negatif terhadap cara belajar mereka. Dari data survei menunjukkan sebanyak $80 \%$ responden menyadari bahwa menggunakan Brainly akan berdampak negatif pada cara belajar mereka, sedangkan sisanya sebanyak 20\% menjawab bahwa Brainly tidak menimbulkan dampak negatif.

Aplikasi Brainly terbukti dapat meningkatkan hasil belajar siswa, namun disamping itu juga berdampak negatif terhadap cara belajar siswa di kelas. Para pendidik dan orangtua siswa diharapkan selalu mengawasi anak-anak didiknya dalam memanfaatkan teknologi pembelajaran di sekolah ataupun di rumah. Para siswa juga perlu dilatih untuk rajin membaca buku agar tidak selalu bergantung pada kemudahan teknologi saat ini, salah satunya penggunaan Brainly.

\section{DAFTAR PUSTAKA}

Kasiram, Moh. 2008. Metodologi Penelitian. Malang: UIN-Malang Pers.

Al-qobi, F. (2021). Penggunaan Aplikasi Brainly Dalam Meningkatkan Pemahaman Siswa Dalam Proses Pembelajaran. Jurnal Sosial Sains. 2(2), 70-75.

Asniar, A., Muharam, L. O., \& Silondae, D. P. (2020). Faktor-Faktor Penyebab Rendahnya Minat Baca Siswa. Jurnal Ilmiah Bening: Belajar Bimbingan Dan Konseling, 4(1), 9-16.

Rusydi, I. (2019). Peranan Perkembangan Teknologi. Journal of Chemical Information and Modeling, 53(9), 1689-1699.

Gunawan, Z. (2014). Pemanfaatan Teknologi Informasi dan Komunikasi (TIK) dalam Pembelajaran. Jurnal Ilmiah Pendidikan Fisika Al-Biruni, 3(1), 71-78.

Lestari, S. (2018). Peran Teknologi dalam Pendidikan di Era Globalisasi. Edureligia; Jurnal Pendidikan Agama Islam, 2(2), 94100.

https://doi.org/10.33650/edureligia.v2i2.4 59

Marryono Jamun, Y. (1996). Dampak Teknologi Terhadap Pendidikan. 10, 4852.

Rusydi, I. (2019). Peranan Perkembangan Teknologi. Journal of Chemical Information and Modeling, 53(9), 16891699.

https://www.neliti.com/id/publications/29 0643/peranan-perkembangan-teknologiinformasi-dan-komunikasi-dalamkegiatan-pembelaja

Yona, N., Munti, S., \& Syaifuddin, D. A. (2020). Analisa Dampak Perkembangan Teknologi Informasi Dan Komunikasi Dalam Bidang Pendidikan. 4, 1799-1805.

Rahman, A. (2016). Pengaruh Negatif Era Teknologi Informasi Dan Komunikasi Pada Remaja (Perspektif Pendidikan Islam). Al-Ishlah, 14(1), 21. 